\title{
МЕТОДИ ВИМІРЮВАННЯ НАПРУЖЕНЬ НА МЕЖІ ПРИЙМАЛЬНА ГІЛЬЗА - ЗАЛИШКОВА КІНЦІВКА
}

\author{
Мельник Г. В., асист. кафедри \\ annamelnyk1996@gmail.com \\ Худецький I. Ю., д.мед.н., проф. \\ igorkhudetskyy@gmail.com \\ Антонова-Рафі Ю. В., к.Т.н., доц. \\ antonova-rafi@ukr.net \\ Національний технічний університет України \\ «Київський політехнічний інститут імені Ігоря Сікорського», \\ м. Київ, Україна
}

\begin{abstract}
Реферат - частота ампутаиій нижніх кінцівок зростає у всьому світі через високий рівень дорожньо-транспортних пригод та судинних захворювань. Транстибіальні ампутанти часто використовують протез як реабілітаційний засіб для відновлення повсякденної діяльності. Протез складається з кількох важливих компонентів, таких як приймальна гільза, подовжувач, щииколотка та стопа. Приймальна гільза забезпечує з'єднання між залишковою кінцівкою (куксою) та іншими компонентами протезного пристрою. Встановлення та конструкція приймальної гільзи є найскладнімою процедурою через унікальність та складність залишкової кінцівки кожного ампутованого. Незручний протез через неправильне встановлення на залишковій зоні роз'єму кіниівки може призвести до надмірних навантажень, пістонтів (вертикальні рухи всередині гнізда), подразнення шкіри та виразок і навіть до потенційної реампутації. Розподіл напружень між залишковою кінцівкою та приймальною гільзою при транстибіальній ампутаиії розглядається як прямий показник якості пристосування та комфорту приймальної гільзи. У зв'язку з иим, дослідники дуже зацікавлені у кількісній оцінці ичих напружень на межі розділу, щзоб оиінити ступінь будь-якого потенційного пошкодження, спричиненого приймальною гільзою на залишкові тканини кінцівок. Протягом останніх 50 років були використані різноманітні методи вимірювання, для визначення локалізацій надмірних напружень, які можуть призвести до пошкодження шкірних покривів, порівняння розподілу напружень у різних конструкиіях приймальних гільз, а також для оцінки системи амортизації при протезуванні нижніх кінцівок. Результати таких методів вимірювання сприяли вдосконаленню конструкиї та монтажу транстибіальних приймальних гільз. Ця стаття має на меті оглянути принципи роботи, переваги та недоліки традиційних та нових методів, що використовуються для вимірювання напруги на межі приймальна гільза - залишкова кінцівка. У статті також оглянуто еволючію різних концепиій приймальних гільз та досліджень напружень на межі приймальна гільза залишкова кінцівка, проведених за останні п'ять десятиліть, надано уявлення про останні тендениії в дизайні приймальних гільз та наведено міркування щзоо ефективних інструментів вимірювання напружень, які призводять до створення функиіональної приймальної гільзи.
\end{abstract}

Ключові слова: приймальна гільза; транстибіальний ампутант; вимірювання напружень; залишкова кінцівка, тензодатчики, n'єзорезистивні датчики, п'єзоелектричні датчики, ємнісні датчики, оптичні датчики.

\section{I. ВСТУП}

Розробка приймальних гільз вимагає точного балансу таких факторів, як розподіл тиску, температура та гігієна. Зміни в об'ємі залишкової кінцівки можуть спричинити значні проблеми 3 придатністю приймальної гільзи, а результуючі профілі навантажень можуть створити незліченну кількість шкідливих станів для здоров'я пацієнта. Конструкції приймальних гільз та підвісні механізми зазвичай обираються протезистом на основі таких факторів, як розмірні особливості залишкової кінцівки, м'язова трофіка, рівень активності та спосіб життя. Якість отриманої конструкції сильно залежить від досвіду протезиста. Не існує стандартного пристрою, за допомогою якого протезисти можуть створювати приймальні гільзи оптимального прилягання, підвішування та вирівнювання, або за допомогою яких вони можуть оцінювати такі фактори. Більшість методів оцінки приймальної гільзи спираються на візуальні методи. Для протезистів дуже важливо повністю зрозуміти взаємозв'язок між конструкцією приймальної гільзи та профілем напружень, яким вони піддають залишкову кінцівку. Складність поверхні кінцівки 3 
урахуванням зміни іï об'єму вимагає кількісних вимірювань у режимі реального часу для забезпечення безпечного використання протезів нижніх кінцівок та відповідної конструкції приймальної гільзи.

\section{II. МЕТА РОБОТИ}

Оглянути принципи роботи, переваги та недоліки традиційних та нових методів, що використовуються для вимірювання напруги на межі приймальна гільза залишкова кінцівка.

\section{III. ТЕНЗОРЕЗИСТИВНІ ДАТЧИКИ}

Тензорезистивні датчики (ТД), або тензометричні перетворювачі - це металеві електричні вимірювальні елементи, які точно розпізнають сили, навантаження, крутний момент $\mathrm{i}$ т. д. насамперед $\mathrm{y}$ статичному діапазоні. Принцип дії тензометрического перетворювача заснований на фізичному ефекті зміни електричного опору провідника при його розтягуванні або стисненні, який пропорційний поздовжньої деформації [1].

Тензорезистивні датчики мають ряд недоліків, оскільки вони дуже сприйнятливі до вологості та перепадів температур, погано працюють на криволінійних поверхнях, демонструють високий гістерезис i часто нелінійну реакцію [2]. Для подолання наведених проблем вони зазвичай використовуються в конфігурації мосту Уітстона (рис. 1).

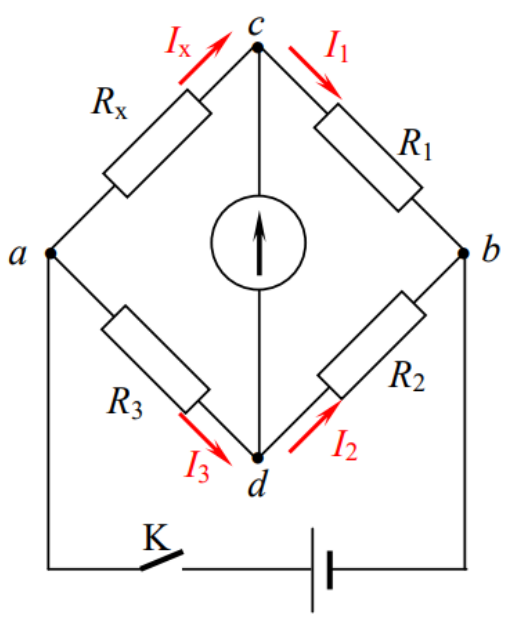

Рис. 1 Принципова схема моста Уітстона
Міст складається 3 опору $R_{x}$, який треба визначити, і трьох відомих опорів $R_{1}, R_{2}, R_{3}$, що утворюють замкнений чотирикутник [3]. Опори $R_{1}, R_{2}, R_{3}$ утворюють плечі моста, а джерело ЕРС і гальванометр введені в його діагоналі [3].

Мостовий метод має обмеження: його не можна використати для вимірювання малих опорів, оскільки за цих умов через схему буде протікати великий струм, що призведе до появи значних похибок вимірювання [3].

Фактор тензочутливосі (чутливість) визначається відносною зміною опору датчика щодо відносної зміни довжини, заданий рівнянням нижче [4].

$$
G F=\frac{\Delta R / R}{\Delta L / L}=\frac{\Delta R / R}{\varepsilon}
$$

Де $G F$ - фактор тензочутливості, $\mathrm{R}$ - опір, L довжина, a $\varepsilon$ - деформація [4]. Механічне напруження, прикладене до калібру, спричиняє різницю в ширині та довжині сітки, впливаючи на спостережуваний електричний опір (рис. 2)

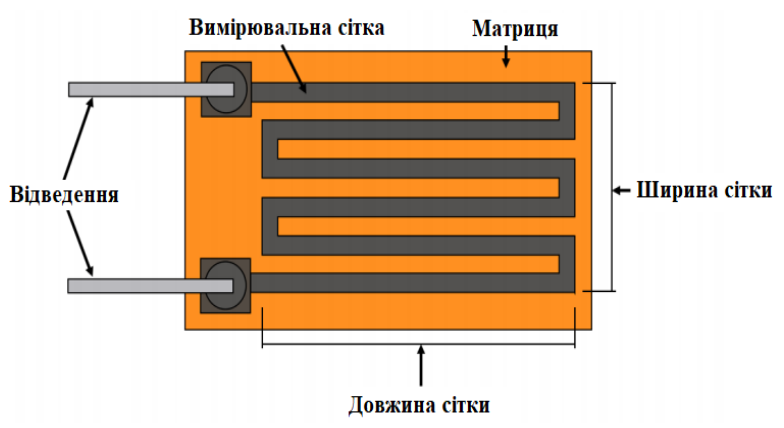

Рис. 2 Структура тензорезистивного датчика

Першим перетворювачем на основі ТД, здатним вимірювати лише прямий тиск, був датчик Куліте в 1970 р. [5]. Діаметр та товщина чутливого елемента складали 3,2 та 0,8 мм відповідно. Датчик виконаний монолітним і має жорстку основу, щоб утримувати його рівним, коли він прикріплений до криволінійних поверхонь. Незважаючи на свою простоту, високу чутливість та малу вагу, він мав кілька обмежень. Його жорстка підкладка не узгоджувалася із залишковими тканинами кінцівок та вкладишем, викликаючи концентрацію напруги на краях датчика, особливо в анатомічно вигнутих областях, призводячи до місцевого натягу шкіри та змінюючи розподіл тиску [5].

Перетворювачі поршневого типу використовуються для зменшення перехресних зв'язків та проблем із концентрацією напруг на 
краях датчиків, однак вони вимагають значної модифікації приймальної гільзи (ПГ), включаючи свердління отворів у ПГ та громіздкий поршневий корпус, прикріплений до зовнішньої сторони. Проблеми з гістерезисом та заклинюванням відзначаються, коли поршень не підтримується в чистоті [6]. Перша запропонована концепція перетворювача поршневого типу являла собою ТД, розміщений у циліндрі (рис. 3) [6]. Поршень передає поверхневий тиск на малу балку, оснащену ТД і затиснуту на ії кінцях до дистального кінця рами циліндра [6]. Цей перетворювач продемонстрував відповідну чутливість до напружень і не був чутливим до перешкод. Однак це був односпрямований перетворювач, що вимірював лише нормальні напруження. Зовнішні напруження, що діють на залишкову кінцівку, являють собою поєднання нормальних і зсувних напружень. Таким чином, напруги зсуву не менш важливі, ніж нормальні, оскільки вони можуть зменшити шкірний кровотік, спричиняючи ураження шкіри [7].

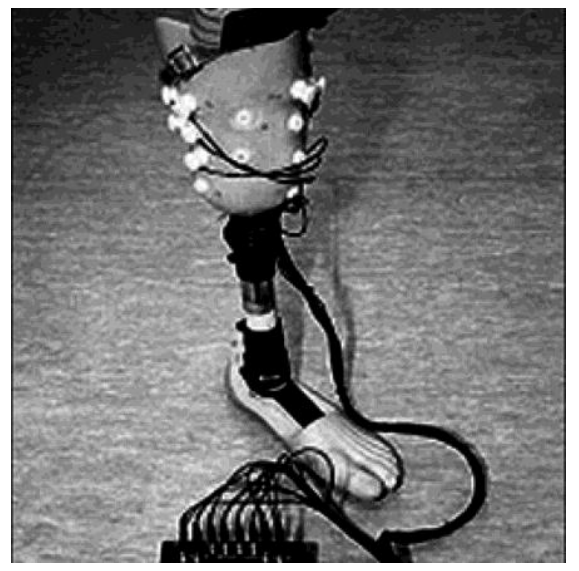

Рис. 3 Система для зняття напружень на основі перетворювача поршневого типу [6]

\section{IV. П'ЄЗОРЕЗИСТИВНІ ДАТЧИКИ}

П'єзорезистивні датчики (ПРД) покладаються на електричні властивості чутливого до тиску елемента, який змінює опір під навантаженням. Фактично ПРД працює як змінний резистор. Принцип зондування п'єзорезистивного перетворювача відрізняється від ТД тим, що опір ПРД змінюється в залежності від деформації внаслідок прикладеного тиску, а опір тензорезистора змінюється в залежності від деформації внаслідок деформації форми [8].

Більшість дослідників вважають за краще використовувати п'єзорезистивні датчики, завдяки їх особливим характеристикам, включаючи тонку конструкцію, малий профіль, гнучкість, хорошу чутливість, відносно просту структуру та простоту використання $[9,10]$. ПРД можуть бути виготовлені у різних формах та розмірах, щоб використовувати їх для вимірювання швидкості змін прикладених сил та виявлення контактного тиску між двома поверхнями. На відміну від ТД, які можуть бути розміщені всередині ПГ або встановлені на стінці ПГ, всі ПРД є дуже тонкими листами; що ідеально підходить для розміщення всередині ПГ.

Стандартні ПРД виготовляються з чутливого до тиску елемента у формі еластомеру, струмопровідної фарби та струмопровідного каучуку або вуглецевого волокна, яке укладено між двома шарами гнучких поліефірних плівок, склеєних клеєм [11]. Як правило, вони працюють за рахунок змінного опору величиною більше 1 МОм при розвантаженні. Якщо на поверхню датчика прикладається підвищений тиск, то опір відповідно падає [9, 12]. Електричний опір розраховується за такою формулою:

$$
R=\frac{\rho \cdot l}{A}
$$

де $\rho, l$ та $A$ позначають об'ємний опір, довжину та площу поперечного перерізу п'єзорезистора відповідно. Зазвичай зміна опору перетворюється на відповідну вихідну напругу за допомогою конфігурації мосту Уітстона [8].

На рис. 4 представлена типова конструкція п’єзорезисора. При виникненні тиску активна область нанесеного малюнка електрода змушена контактувати 3 провідною плівкою, змінюючи спостережуваний опір.

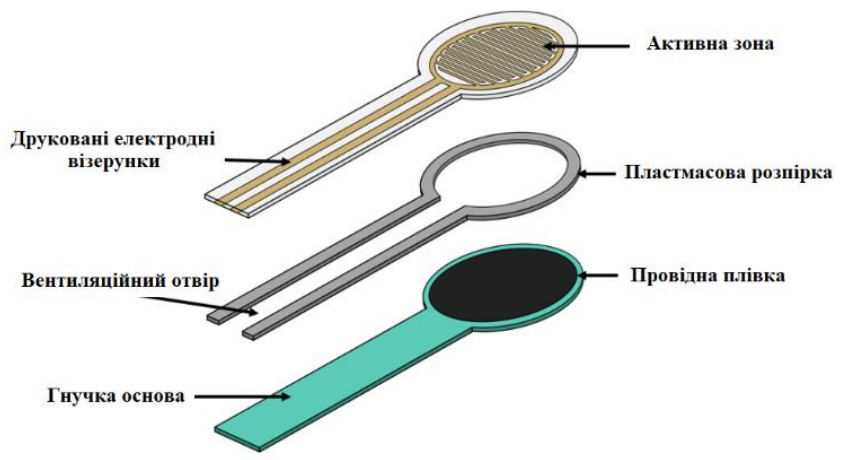

Рис. 4 Конструкція ПРД [4] 
У 2013 році створено сенсорну мережу, що містить п'ять датчиків FlexiForce, вирівняних у спеціальній конфігурації та вбудованих у гнучкий тонкий лист ацетату (рис. 5) [13]. Проте, ця конфігурація все ще неефективна для вимірювання залишкових напружень на кінцівках, оскільки вона має дуже малу чутливу поверхню.

\section{Виготовлення сенсорної мережі}

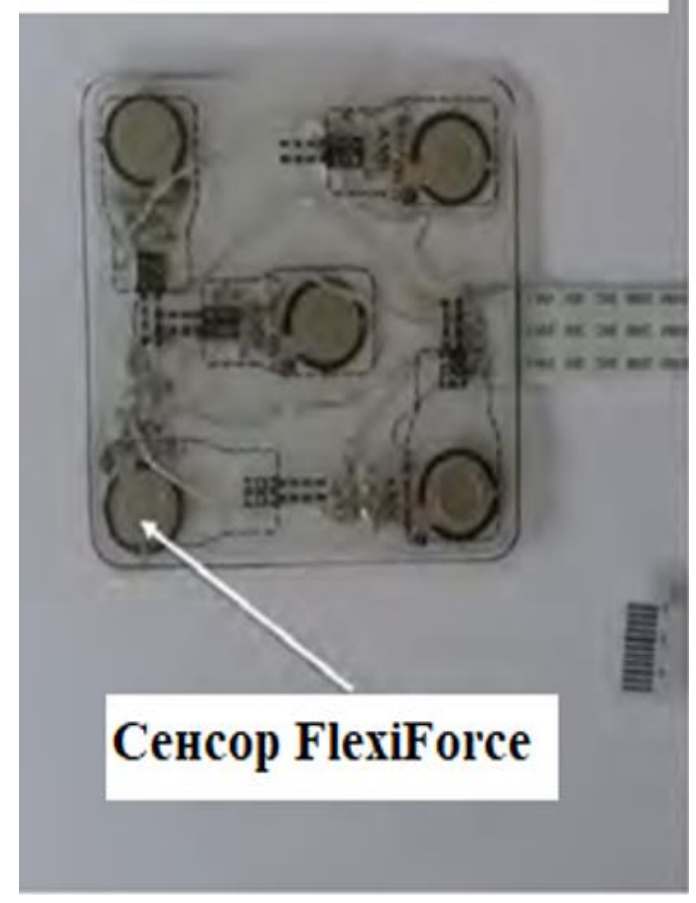

Рис. 5 Сенсорна мережа на основі датчиків FlexiForce [13]

Системи Rincoe Socket Fitting та FSocket $\epsilon$ найбільш відомими системами на основі ПРД для вимірювання тиску на межі ПГ - залишкова кінцівка. Обидві системи не потребують модифікацій в ПГ, що робить їх зручнішими в порівнянні 3 поршневими системами. Система Rincoe Socket Fitting - це комбінація 60 ПРД, вбудованих у шість смужок фтористого полівінілідину товщиною 0,36 мм. Кожна смуга складається 310 точок для зняття тиску [14].

Перетворювач F-Socket також базується на технології використання ПРД. Він побудований з 96 окремих сенсорних точок, розташованих у матриці з 16 рядків та шести стовпців [9]. Незважаючи на дрейф датчика, гістерезис та чутливість до температури, відтворюваність і чутливість датчика F-Socket вважалася задовільною в лабораторних умовах. Основний недолік датчиків F-Socket пов'язаний з їх нездатністю вимірювати напруги зсуву та їх гістерезисом, що викликає низькочастотну характеристику порівняно 3 ємнісними датчиками.

Дослідження демонструють переваги тонких ПРД в їх здатності забезпечувати хорошу чутливість, роздільну здатність, частотну характеристику, стабільність та динамічну реакцію на циклічне навантаження. Однак існують значні проблеми 3 продуктивністю, властиві обмеженій кількості наявних у продажу систем вимірювання тиску. Значні похибки, проблеми 3 гістерезисом і дрейфом, слабкий вихідний сигнал при дії на криволінійну поверхню, відсутність повторюваності та чутливості до температури - це проблеми, які необхідно вирішувати. Крім того, представлені системи не мають фіксованого формату i часто розміщуються вільно на поверхнях, що представляють інтерес.

\section{V. П'ЄЗОЕЛЕКТРИЧНІ ДАТЧИКИ}

П'єзоелектричні датчики працюють 3 використанням певних матеріалів, що генерують потенціал напруги при механічній деформації. Багато матеріалів мають п'єзоелектричні властивості, включаючи кристали кварцу, берлінджиту та турмаліну, кераміку та полімери, такі як фторид полівінілідену [4]. Кристали кварцу та кераміка, як правило, мають кращі п'єзоелектричні властивості, ніж такі полімери, однак, полімери популярні завдяки своїй гнучкості, стабільності розмірів, невеликій вазі, працездатності та хімічній інертності [4].

Основним принципом ПЕД є те, що сила, діючи на кристал кварцу, виробляє електричні заряди на поверхні кристала. Вироблений таким чином заряд можна назвати п'єзоелектричністю. П'єзоелектричність може бути визначена як електрична поляризація, що утворюється внаслідок механічного напруження певного класу кристалів. Швидкість виробленого заряду буде пропорційна швидкості зміни сили, що приходить на вхід. Оскільки вироблений заряд дуже малий, підсилювач заряду необхідний для отримання вихідної напруги, достатньо великої для вимірювання. 


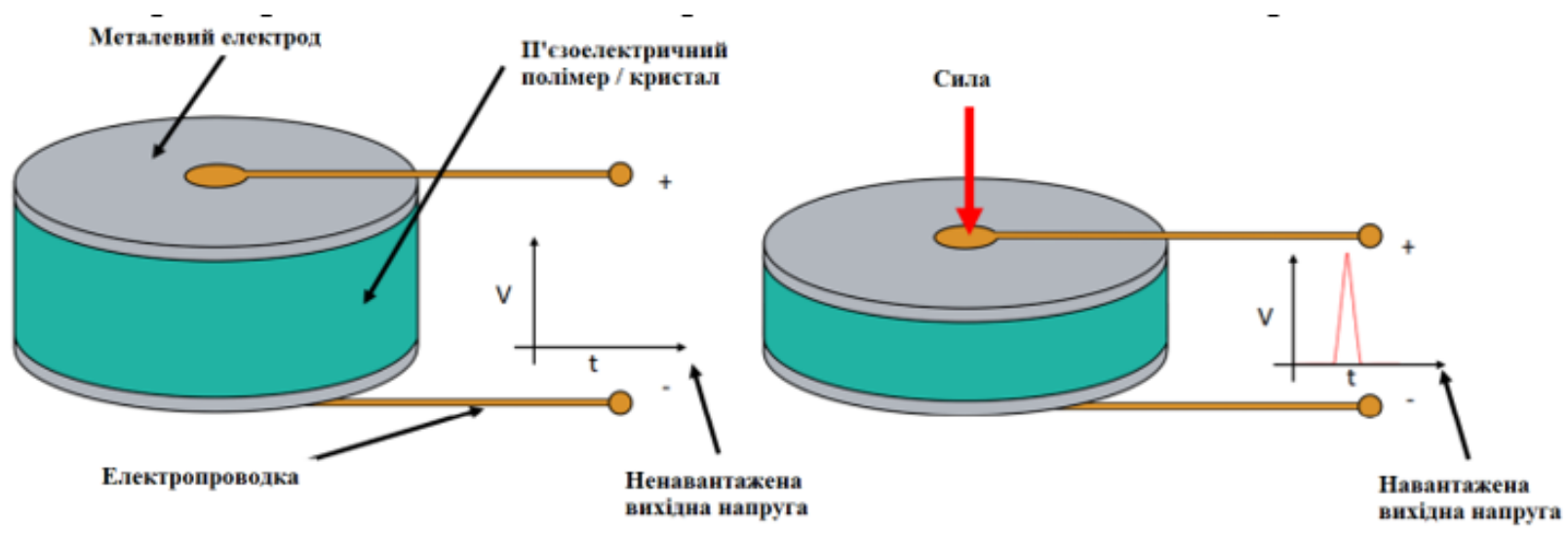

Рис. 6 Принцип роботи п'єзоелектричного датчика тиску [4]

Також відомо, що пристрій має механічну жорсткість. Наприклад, якщо на перетворювач подається сила $15 \mathrm{\kappa H}$, він може відхилятися максимум до 0,002 мм [15]. Але вихідна характеристика може бути до 100 КГц, що доводить, що прилад найкраще застосовувати для динамічних вимірювань [15].

На рисунку 7 зображений звичайний ПЕД 3 п'єзоелектричним кристалом, вставленим між твердою основою та елементом, що підсумовує силу. Якщо до порту тиску прикласти силу, вона передається на елемент, що підсумовує силу. Таким чином, на кристалі буде створюватися різниця потенціалів через його властивості. Вироблена напруга буде пропорційна величині прикладеної сили [15].

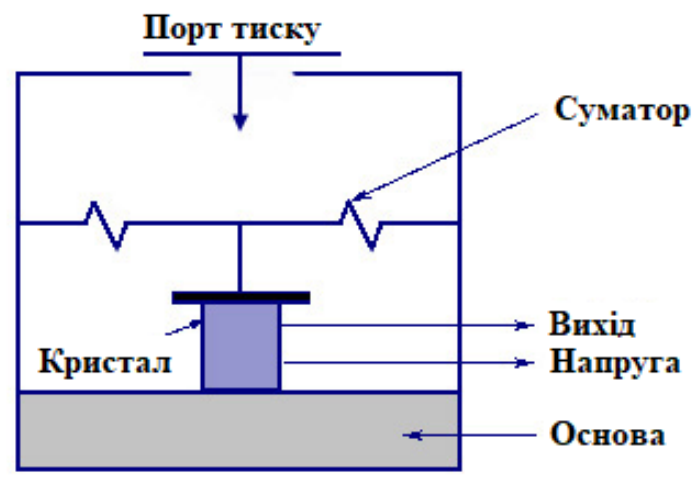

Рис. 7 Конструкція ПЕД [15]

ПЕД мають високу чутливість та $€$ пасивними датчиками i як такі не потребують джерела живлення [9]. ПЕД зазвичай демонструють хорошу високочастотну характеристику, що робить їх ідеальними для вимірювання вібрацій, проте обмежуючи спостереженням динамічних сил [9, $11,8]$. Їх нездатність вимірювати статичні сили випливає з великого внутрішнього опору, через що заряд, що розвивається в кристалі, швидко розпадається з постійною часу [8].

У 2014 році було досліджено використання існуючих готових п'єзоелектричних біморфів як вбудованих датчиків в умовах статичного та динамічного навантаження для трансфеморальних ампутацій. Біморфи складаються 3 двох п'єзоелектричних шарів 3 латунним опорним шаром, затиснутим між ними [16].

Одношаровий п'єзоелектричний привід створює кривизну, коли один п'єзошар розширюється, а інший стискається. Типовим $є$ згинальний рух від сотень до тисяч мікрон та сила згинання від десятків до сотень грамів [17]. Латунна підсилювальна прокладка, встановлена між двома п'єзоелектричними шарами, $\epsilon$ економічним підходом до виготовлення міцного приводу (рис. 8).

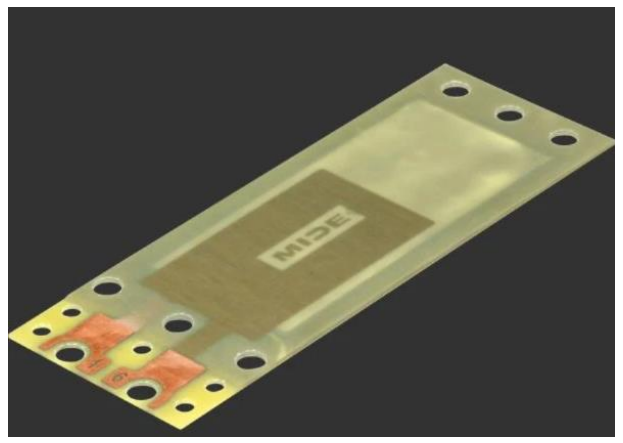

Рис. 8 Система S128-J1FR-1808YB, Piezo Systems [17]

У статичних умовах система була відкалібрована для діапазону, що представляє інтерес, від 0 до 100 Н як в інкрементальних, так і в декрементальних заходах для визначення 
ефектів гістерезису [16]. Динамічне навантаження системи передбачало введення різноманітних синусоїдальних входів. Трансфеморальна ПГ була обладнана трьома біморфами, розміщеними в передньому проксимальному, передньому дистальному та задньому положеннях 3 метою отримання максимального тиску, що чиниться через ПГ. Клінічне випробування проводилось 3 одним пацієнтом, який ходив із довільною швидкістю.

Результати дослідження свідчать про тісний зв'язок між прогином біморфа та вихідною напругою 3 м'яким ефектом гістерезису. Показано, що пристрій насичується при 30 кПа, вказуючи робочий діапазон від 0 до 25 кПа [16]. У статті продемонстровано п'єзоелектричних біморфів для вимірювання тиску в ПГ, підкреслюючи їх силу в діапазоні динамічного зондування. Цей різновид готових біморфів явно не має діапазону дії, відповідного для вимірювання тиску в ПГ. Межа вимірювання при 30 кПа перешкоджає системі фіксувати важливі виникнення високого тиску, враховуючи, що найвищий зафіксований піковий тиск для ПГ, що несе сухожилля надколінка, перевищує 300 кПа [18].

\section{VI. ЄМНІСНІ ДАТЧИКИ}

Ємнісний датчик складається 3 діелектричного матеріалу, укладеного між двома паралельними провідними поверхнями. Він може бути налаштований на основі двох принципів переміщення (рис. 9). Перший підхід залежить від зміни площі поверхні, що перекривається, між двома провідними поверхнями, що робить ii більш привабливою завдяки високій точності. Другий підхід залежить від відстані між двома провідними поверхнями [11]. Смність може бути виражена як:

$$
C=\frac{A \cdot \varepsilon_{0} \cdot \varepsilon_{r}}{d}
$$

де $C$ - ємність, $A$ - площа перекриття двох поверхонь, $\varepsilon_{0}$ - діелектрична проникність вільного простору, $\varepsilon_{r}$ відносна діелектрична проникність діелектричного матеріалу i $d$ - відстань між пластинами [13].
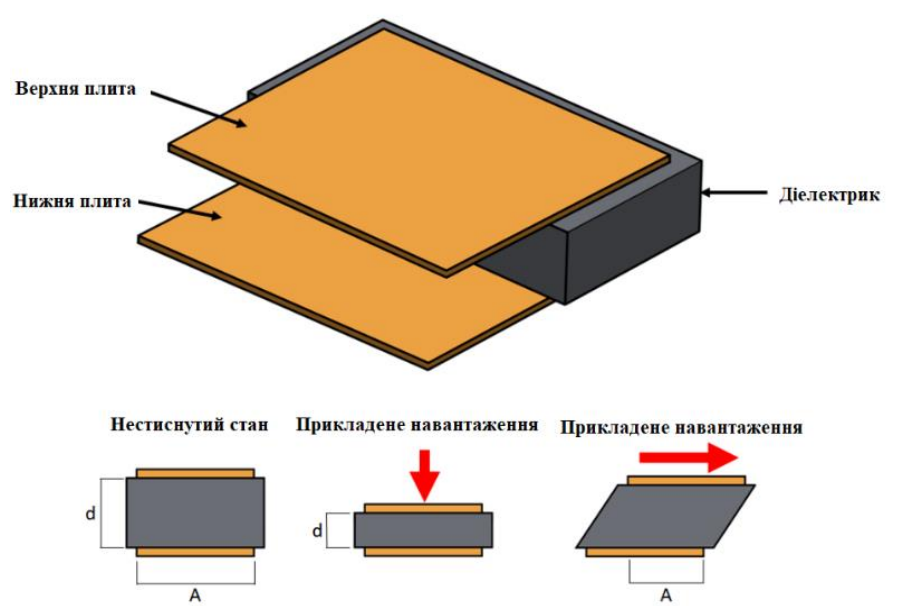

Рис. 9 Базова конструкція СД [4]

Принцип зсуву, заснований на зміні площі перекриваючих поверхонь плит, забезпечує високу точність і постійну чутливість відповідно до наступного рівняння [4]

$$
\frac{d C}{d A}=\frac{\varepsilon_{0} \cdot \varepsilon_{r}}{d}
$$

Другий підхід, який використовує відстань між пластинами, простіший у проектуванні, однак він призводить до нелінійного співвідношення між $C$ i $d$ зі змінною чутливістю, що характеризується наступним рівнянням [4]

$$
\frac{d C}{d d}=\frac{-A \cdot \varepsilon_{0} \cdot \varepsilon_{r}}{d^{2}}
$$

Смнісні датчики, як правило, мають добру частотну характеристику, високу просторову роздільну здатність, високу чутливість, низькі вимоги до потужності, хороші властивості дрейфу та гістерезису, високу просторову роздільну здатність та великий динамічний діапазон $[2,9]$. Ємнісні датчики сприйнятливі до шуму, особливо при мультиплексуванні в конфігурації сітки [2, 11]. Отже, для фільтрації шуму потрібна складна та потенційно дорога електроніка. Ряд груп як у комерційній, так і в дослідницькій сферах досліджували характеристики ємнісних перетворювачів при визначенні тиску в ПГ.

У 1973 р. було повідомлено про першу спробу використання ємнісного датчика для вимірювання тиску в ПГ [19]. Були розроблені гнучкі, недорогі ємнісні датчики, кожен з яких був товщиною 2 мм i міг вставлятися на межу між залишковою кінцівкою та ПГ. На основі проведених стендових 
випробувань експлуатаційна точність склала 20\%. У 1998 році виготовлений прототип ємнісного датчика «Novel» вигляді матричної масиву 316 сенсорних ділянок (4 мм х 4 мм), вмонтованих у силіконову підкладку (2,5 cм х 2,5 cм) товщиною 0,63 мм. Гнучка підкладка дозволяла розтягуватися до 4\%. [20]. Одночасно можна було підключити до 16 масивів, щоб забезпечити в цілому 256 вимірювань [20]. Зазвичай він вставляється між шкірою та вкладишем або між вкладишем та ПГ. Стендові випробування iз використанням стисненого повітря проводились для оцінки достовірності прототипу датчика « Novel» 3 точки зору точності, гістерезису, ефекту кривизни та реакцій на дрейф як у планшетній камері, так і в спеціально модифікованій посудині під тиском. Потім нові датчики розміщувались у дев'яти різних місцях на залишкової прес-формі для кінцівок, огорнутій силіконовою підкладкою. Для клінічної оцінки даної конструкції датчика в цьому дослідженні брали участь два пацієнта 3 транстибіальною ампутацією. Було відзначено, що система має низькі похибки як у плоских, так і в контурних середовищах, величиною $2,42 \%$ та $9,96 \%$ відповідно [20]. Помилки гістерезису, у той час як плоскі так i контурні, були зафіксовані як $12,93 \%$ та $12,95 \%$ відповідно [20]. Також спостерігалась помилка дрейфу на плоских та контурних середовищах 4,4\%, 6,2\% відповідно [20]. Система продемонструвала розумну довговічність та хорошу адгезію. Стендові тести та клінічне дослідження не показали помітного зсуву датчика між значеннями калібрування до та після тесту після трьох годин безперервного використання. Це також показало прийнятну надійність та точність [21]. Однак при низькому тиску були зафіксовані великі коливання напруги на виході. Також така конструкція датчика все ще односпрямована, вимірюючи лише прямий тиск. Пізніше було повідомлено про декілька тривісних датчиків напруги, але їх використання в ПГ було обмежене через їх жорсткі основи, які не відповідають залишковій геометрії кінцівок [22, 23], та їхні складні технології виготовлення, що заважають виготовленню кількох масивів датчиків [24].

\section{VII. ОПТИЧНІ ДАТЧИКИ}

Волоконно-оптичні датчики (ВОД) були введені в область медицини в 1960-х роках [25]. Найпоширеніші методи вимірювання, застосовувані до ВОД у галузі біомеханіки, базуються на інтенсивності [26], фазі [27] та модуляції довжини хвилі [28], причому остання пов'язана 3 роботою волоконних датчиків на основі Брегівської решітки (ВБД). ВБД залучили багатьох дослідників завдяки своїм чудовим перевагам, серед яких висока чутливість, довговічність, стійкість до електромагнітних перешкод, незмінюваність та стійкість до суворих умов [29, 30]. У біомеханіці та реабілітаційній техніці були продемонстровані ВБД для вимірювання найрізноманітніших параметрів; включаючи деформацію всередині та на поверхні кісток, напруження усадки в кістковому цементі під час полімеризації, картографування тиску в ортопедичних суглобах, напруження в міжхребцевих дисках, деформацію в грудній стінці для вивчення біомеханіки легенів, сили індуковані сухожиллями та зв'язками, кути між сегментами тіла під час ходи та багатьма іншими в стоматологічній біомеханіці [31]. Дійсно, вони здаються потенційною альтернативою тензорезистивним, п'єзорезистивним, ємнісним та електромеханічним датчикам тиску [32].

ВБД має подовжню періодичну зміну показника заломлення $n_{e f f}$, записаного в серцевину оптичного волокна різними методами: фазова маска, пряме написання або комбінація фазової маски та інтерферометрії для створення необхідного просторового малюнка [33, 34]

Коли оптичне волокно 3 ВБД з'єднане 3 джерелом світла і піддається будь-яким зовнішнім механічним силам, світло, що проходить через нього, буде відбиватися самим ВБД на довжині хвилі Брега, $\lambda_{B}$, в залежності від інтервалу між періодичними варіаціями i деформаційнооптичним ефектом [31]. Принципи роботи проілюстровані на рисунку 10. Відбитий спектр залежить від показника заломлення $\left(n_{e f f}\right)$ та періоду решітки Брегг а $(\Lambda)$, згідно 3 наступним рівнянням [31]:

$$
\lambda_{B}-2 \cdot n_{e f f} \cdot \Lambda
$$


Коли датчик ВБД піддається зовнішнім механічним або термічним збуренням, відбита назад пікова довжина хвилі буде зміщена (Рисунок 10 (б)) відповідно до того, наскільки зовнішні збурення впливають на ВБД, який є спектрально чутливим при дії осьової деформації. визначення довжини хвилі Брегга $\lambda_{B}$ для експериментів у лабораторія х зазвичай використовують оптичні аналізатори спектра (OAC).

Здатність ВБД вимірювати тиск на межі між залишковими кінцівками і ПГ вперше була досліджена дослідниками з Центру прикладної

(a)

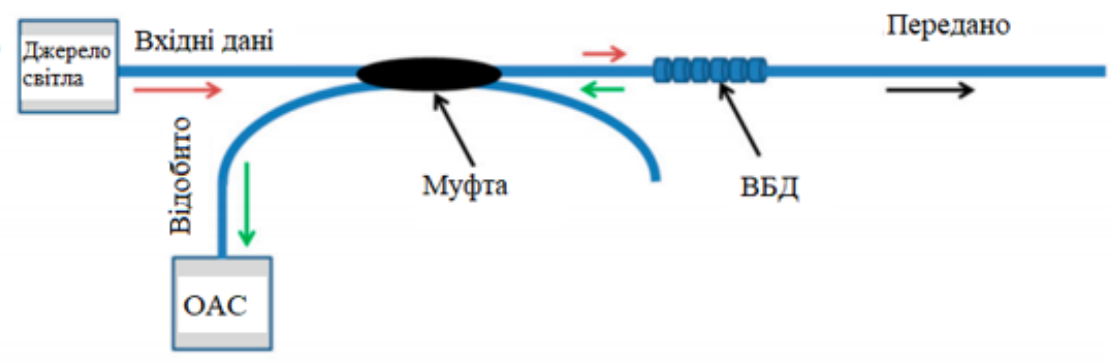

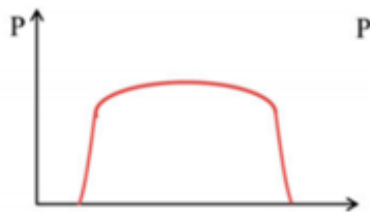

Вхідні дані

(б)

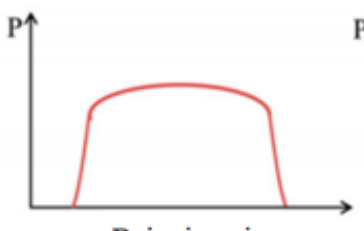

Вхідні дані

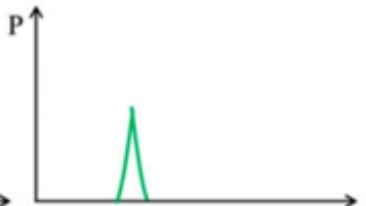

Відобито $\left(\lambda_{\mathrm{B}}\right)$

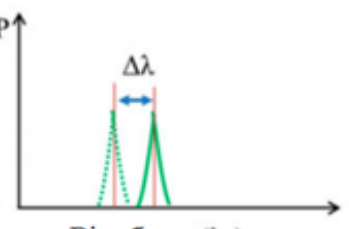

Відобнто $\left(\lambda_{\mathrm{B}}\right)$

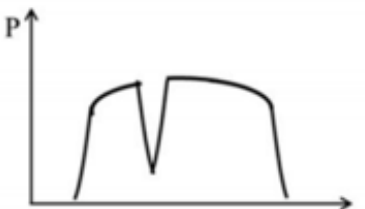

Передано

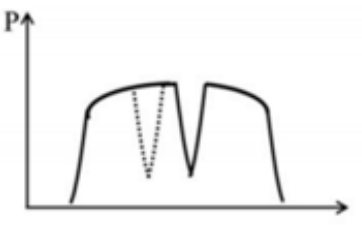

Передано

Рис. 10(а) Джерело світла передається через ВБд, а вузька смуга (зелений колір)

відображається назад, відцентровується навколо $\lambda_{B}$ і контролюється ОАС. (б) Світловідбита

смуга змішується $(\Delta \lambda)$ незабаром після застосування зовнішніх збурень [31]

біомеханіки Університету Малайї в 2013 році [31].

Аксіальна деформація впливає на реакцію ВБД безпосередньо через зміни стиснення та розширення в інтервалі періодичної зміни, $\Lambda$, а також через деформаційно-оптичний ефект, який викликає зміну ефективного показника оптичного волокна, $n_{\text {eff }}$. Приріст температури $\Delta T$ також впливає на показник заломлення та період решітки, що призводить до зміни $\lambda_{B}$. Вплив деформації та температури навколишнього середовища на період решітки та показник заломлення можна виразити наступним чином [31]:

$$
\begin{aligned}
\Delta \lambda_{B}=2\left[\Lambda \frac{\partial n}{\partial l}\right. & \left.+n \frac{\partial \Lambda}{\partial l}\right] \Delta l \\
& +2\left[\Lambda \frac{\partial n}{\partial T}+n \frac{\partial \Lambda}{\partial T}\right] \Delta T
\end{aligned}
$$

де $\Delta l$ - зміна довжини ВБД, спричинена деформацією, $\Delta T$ - зміна температури. Для
Пізніше, у 2015 році, ті самі дослідники вдосконалили конструкцію датчика і виготовили розширюваний спектр ВБД, які можна було вставити в ПГ, щоб створити загальне враження про розподіл тиску по всій поверхні залишкової кінцівки [35]. Тільки один пацієнт брав участь у цьому дослідженні, щоб клінічно підтвердити результати цього датчика. Результати показали, що масив ВБД здатний успішно вимірювати тиск на межі ПГ - залишкова кінцівка. Для оцінки достовірності датчика ВБД його результати порівнювали 3 результатами, отриманими за допомогою комерційно доступної системи Fsocket. Датчики ВБД відображали більшу величину тиску на всіх ділянках зондування. Це могло бути пов'язано 3 товщиною сенсорних майданчиків ВБД, проте схема тиску була однаковою для обох типів датчиків. Цю конструкцію датчика потрібно протестувати на більшому розмірі вибірки для подальшої валідації висновків. 
Моніторинг дотичних напружень стає все більш важливим при дослідженні ПГ. Усі попередні конструкції датчиків ВБД могли вимірювати лише прямий тиск. У 2013 році було повідомлено про полімерний ВБД датчик, здатний вимірювати нормальні та зсувні напруження [36]. Датчик складався з двох полімерних ВБД, вбудованих у м'яку матрицю, один 3 яких розміщений горизонтально, а інший нахилений по всій матриці, як показано на рисунку 11. Для фіксації решіток на їх кінцях використовували чотири прокладки. Результати показали, що датчик добре працював і міг визначати тиск та напруги зсуву. Незважаючи на свою високу чутливість, цей м'який датчик може бути придатним для вимірювання низьких нормальних та зсувних напружень.

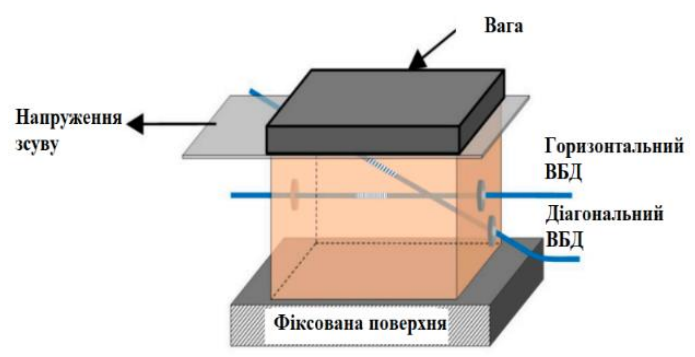

Рис. 11 Конструкція полімерного ВБД датчика

Оптоелектронні датчики (ОЕД), що містять друковану плату, були використані в протезуванні для вимірювання прямих навантажень та навантажень зсуву. ОЕД, виготовлений із зовнішньої силіконової рухомої конструкції, та друкованої плати, яка вміщує безліч чутливих елементів, були введені для контролю розподілу тиску на межі ПГ - залишкова кінцівка та стопа земля. [37]. Кожен чутливий елемент складається 3 передавача світла, світлодіода, приймача та фотодіода. На рисунку 12 показано структуру датчика та те, як силіконова конструкція відіграє важливу роль у принципі трансдукції. При виникненні навантаження на датчик силіконова маса деформується сама. Інтенсивність світла, що надходить від фотодіода, пропорційно варіює його вихідну напругу. Однак ця конструкція практично не оцінювалась у ПГ.

Іншу конфігурацію ОЕД розроблена у 2010 р. [38]. Продемонстровано нову концепцію датчика зсуву, яка є дуже тонкою та гнучкою та працює на основі зміни оптичної потужності між випромінювачем (лазером) та приймачем (фотодіодом), розділеним деформованим чутливим шаром. Структура датчика деформується під впливом зовнішніх зсувних сил, що призводить до зміни інтенсивності потужності, яку отримує фотодіод. Встановлено, що ця концепція датчика відтворювана і під впливом нормальних напружень.

Однак у ОСД є кілька недоліків, таких, що їх повна робота може бути ускладнена через будь-які пошкодження оптичного волокна або оптоелектронних компонентів [29]. Крім того, електричні системи типу, такі як ОЄД, сприйнятливі до електромагнітних перешкод [39]. ВБД мають невеликі розміри, легкі, високочутливі та міцні. Залежності температури та тиску оптичних датчиків є лінійними, тому їх можна взаємно компенсувати. Ключовою перевагою ВБД $\epsilon$ ïх несприйнятливість до електромагнітних перешкод, що робить їх потенційним кандидатом на заміну існуючим вимірювальним системам, що використовуються для вимірювання тиску на межі ПГ - залишкова кінцівка. Труднощі виникають із надійністю та несумісністю 3 існуючим обладнанням через новий характер технології оптичного зондування.

\section{VIII. ВИСНОВОК}

Очевидно, що нормальні та дотичні напруження розподілу в транстибіальних приймальних гільзах були досліджені за допомогою різноманітних вимірювальних систем, розроблених протягом останніх п'яти десятиліть. Використання таких систем значно допомогло дослідникам/протезистам чітко зрозуміти механічну взаємодію між залишковою кінцівкою

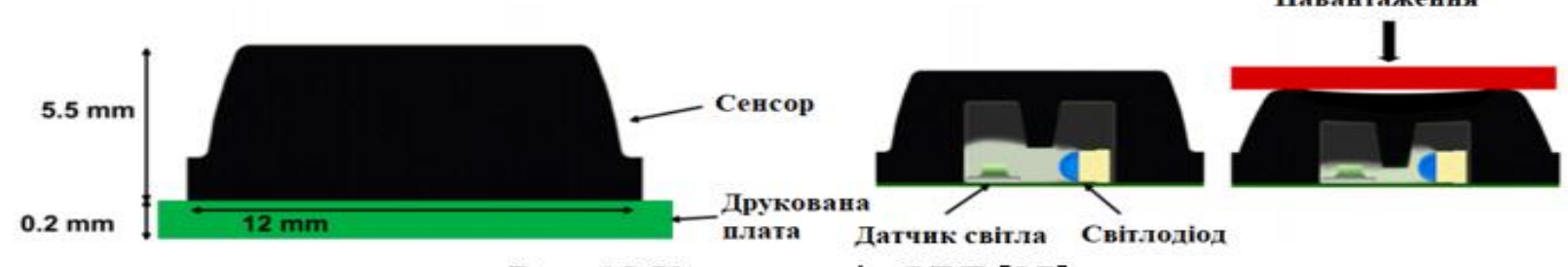

Рис. 12 Конструкція ОЕД [37] 
та приймальною гільзою, що сприяло покращенню конструкцій приймальних гільз. Кілька систем (наприклад, Tekscan i Pliance) були комерційно доступними i могли бути ефективними в клінічних умовах, але вони не в змозі виміряти напруги зсуву, які мають велике значення для дослідників, оскільки вони здатні викликати виразки на шкірі та подразнення на залишковій кінцівці. 3 іншого боку, датчики що працюють за принципом вимірювання деформацій здатні вимірювати як нормальні, так і напруги зсуву, але їх об'ємність перешкоджала їх використанню в клінічних умовах. На відміну від звичайних перетворювачів, які зазвичай встановлюються на стінці приймальної гільзи нові оптичні датчики та оптоелектронні перетворювачі можуть бути вбудовані безпосередньо в стінку приймальної гільзи або силіконовий вкладиш, усуваючи будь-які спотворення вимірювань, що виникають через об'ємність та/або складку звичайних перетворювачів.

\section{ІХ. ПЕРЕЛІК ПОСИЛАНЬ}

1 «Тензорезистивный датчик,» [Інтернет ресурс]. Available: https://www.kistler.com/ru/glossary/term/straingauge/. [Дата зверненняя: 21 квітень 2021].

2 L. Paterno, M. Ibrahimi, E. Gruppioni, A. Menciassi и L. Ricotti, «Sockets for limb prostheses: a review of existing technologies and open challenges,» IEEE Transactions on Biomedical Engineering, т. 65, № 9, pp. 1996-2010, 2018.

3 Методичні вказівки до лабораторних робіт 3 фізики для студентів усіх форм навчання: Визначення опору провідника за допомогою моста сталого струму (моста Уітстона), Київ, 2015.

4 M. Hopkins, Smart sockets for lower limb prostheses, London, 2019, p. 241.

5 F. Appoldt, L. Bennett и R. Contini, «Tangential pressure measurements in above-knee suction sockets,» Bull. Prosthet. Res., p. 70-86, 1970.

6 F. Appoldt, L. Bennett и R. Contini, «Stump-socket pressure in lower extremity prostheses,» J Biomech, 2 May 1969.

7 M. Zhang, . A. Turner-Smith , А. Tanner и V. Roberts, «Clinical investigation of the pressure and shear stress on the trans-tibial stump with a prosthesis,» Med. Eng. Phys., p. 188-19, 1998.

8 P. Saccomandi, E. Schena, C. M. Oddo, L. Zollo, S. Silvestri и . E. Guglielmelli, «Microfabricated tactile sensors for biomedical applications: A review,» Biosensors, p. 422448, 2014.

9 A. Almassri, . W. Wan Hasan, S. Ahmad, A. Ishak, A. Ghazali, . D. Talib и C. Wada, «Pressure sensor: State of the art, design, and application for robotic hand,» Sensors, 2015 .

10 J. Schofield, . K. Evans, J. Hebert, P. Marasco и . J. Carey, "The effect of biomechanical variables on force sensitive resistor error: Implications for calibration and improved accuracy,» Biomech. , p. 786-792, 2016.

11 M. Tiwana, S. Redmond и N. Lovell, «A review of tactile sensing technologies with applications in biomedical engineering,» Sens. Actuators A Phys., p. 17-31, 2012.

12 В. Kane, . M. Cutkosky и . G. Kovacs, «A traction stress sensor array for use in high-resolution robotic tactile imaging,» $\mathrm{J}$. Microelectromech. Syst., p. 425-434, 2000.

13 E. Ruda, O. Sanchez, . J. Mejia, S. Gomez и O. Flautero, «Design process of mechatronic device for measuring the stump stresses on a lower limb amputee,» B Proceedings of the 22nd Intl Congress of Mechanical Engineering, Brazil, 2013.

$14 \quad$ K. Shem, . J. Breakey и P. Werner, «Pressures at the residual limb-socket interface in transtibial amputees with thigh lacer-side joints,» J. Prosthet. Orthot., p. 51-55, 1998.

15 «Piezoelectric Transducer,» 27 July 2011. [В Интернете]. Available: http://www.instrumentationtoday.com/piezoelectrictransducer/2011/07/. [Дата обращения: 12 травень 2021].

16 A. M. El-Sayed, N. A. Hamzaid и N. Azuan Abu Osman, «Piezoelectric Bimorphs' Characteristics as In-Socket Sensors for Transfemoral Amputees,» MDPI Sensors , pp. 23724-23741, 2014.

17 «Piezoelectric Bending Transducer,» [B Интернете]. Available: https://piezo.com/products/piezoelectric-bendingtransducer-s128-j1fr-1808yb. [Дата обращения: 22 квітень 2021].

18 A. Eshraghi, A. Osman, H. Gholizadeh, S. Ali и W. Abas, «Interface Stress in Socket/Residual Limb with Transtibial Prosthetic Suspension Systems During Locomotion on Slopes and Stairs,» Motion Analysis, pp. 1-10, 2014.

19 R. Meier, . Е. Meeks и R. Herman, « Stump-socket fit of below-knee prostheses: Comparison of three methods of measurement,» Arch. Phys. Med. Rehabil, p. 553-558, 1973.

20 A. Polliack, D. Craig, R. Sieh, S. Landsberger и D. McNeal, « Laboratory and clinical tests of a prototype pressure sensor for clinical assessment of prosthetic socket fit,» Prosthet. Orthot. Int., p. 23-34, 2002.

21 С. Lai и . C. Li-Tsang, «Validation of the pliance $\mathrm{x}$ system in measuring interface pressure generated by pressure garment,» Burns, $\mathrm{p}$. 845-851, 2009.

22 R. Williams, . D. Porter, V. Roberts и J. Regan, «Triaxial force transducer for investigating stresses at the stump/socket interface,» Med. Biol. Eng. Comput, p. 89-96, 1992.

23 M. А. Razian и M. G. Pepper, «Design, Development, and Characteristics of an In-Shoe Triaxial Pressure Measurement Transducer Utilizing a Single Element of Piezoelectric Copolymer Film,» IEEE Transactions on Neural Systems and Rehabilitation Engineering, pp. 288-293, 2003.

24 K. Sundara-Rajan, A. Bestick, . G. Rowe, G. Klute, W. Ledoux, H. Wang и A. Mamishev, «An interfacial stress sensor for biomechanical applications,» Meas. Sci. Technol., 2012.

25 P. Hugenholtz, W. Gamble, G. Monroe и M. Polanyi, «The use of fiberoptics in clinical cardiac catheterization ii. In vivo dyedilution curves,» Circulation, p. 344-355, 1965.

26 M. Anwar Zawawi, S. O’Keffe и Е. Lewis, "Intensitymodulated fiber optic sensor for health monitoring applications: A comparative review,» Sens. Rev., p. 57-67, 2013.

27 P. Polygerinos, D. Zbyszewsk, T. Schaeffter, R. Razavi, L. Seneviratne и K. Althoefer, «Mri-compatible fiber-optic force sensors for catheterization procedures,» IEEE Sens., p. 1598-1608, 2010.

28 P. Roriz, L. Carvalho, O. Frazao, . J. Santos и J. Simoes, «From conventional sensors to fibre optic sensors for strain and force measurements in biomechanics applications: A review,» J. Biomech., p. 1251-1261, 2014.

29 R. Di Sante, «Fibre optic sensors for structural health monitoring of aircraft composite structures: Recent advances and applications,» Sensors, p. 18666-1871, 2015.

30 S. Mihailov, "Fiber bragg grating sensors for harsh environments,» Sensors, p. 1898-1918, 2012.

31 E. Al-Fakih, N. Abu Osman и F. Mahamd Adikan, «The Use of Fiber Bragg Grating Sensors in Biomechanics and Rehabilitation 
Applications: The State-of-the-Art and Ongoing Research Topics,» Sensors (Basel), p. 12890-12926, 25 September 2012.

32

S. Poeggel, D. Tosi, D. Duraibabu, G. Leen, D. McGrath и E. Lewis, «Optical fibre pressure sensors in medical applications,» Sensors, p. 17115-17148, 2015.

33 A. Abushagur, N. Arsad, M. Reaz и A. Bakar, «Advances in bio-tactile sensors for minimally invasive surgery using the fibre bragg grating force sensor technique: A survey,» Sensors, p. 6633-6665, 2014.

34 B. Quandt, . L. Scherer, . L. Boesel, M. Wolf, . G. Bona и . R. Rossi, « Body-monitoring and health supervision by means of optical fiber-based sensing systems in medical textiles,» Adv. Healthc. Mater., p. 330-355, 2015.

35 E. A. Al-Fakih, N. A. Abu Osman, F. R. Mahamd Adikan, A. Eshraghi и P. Jahanshahi, «Development and
Validation of Fiber Bragg Grating Sensing Pad for Interface Pressure Measurements Within Prosthetic Sockets,» IEEE Sensors Journal, pp. 965-974, 15 Feb 2016.

36 Z. Zhang, X. Tao, H. Zhang и B. Zhu, «Soft fiber optic sensors for precision measurement of shear stress and pressure,» IEEE Sens., $p$. 1478-1482, 2013.

37 A. Al-Fakih, N. Abu Osman и F. Mahmad Adikan , «Techniques for Interface Stress Measurements within Prosthetic Sockets of Transtibial Amputees: A Review of the Past 50 Years of Research,» Sensors, 20 Jul 2016.

38 J. Missinne, E. Bosnian, B. Van Hoe, . G. Van Steenberge, . P. Van Daele и Ј. Vanfleteren, «Embedded flexible optical shear sensor,» в Proceedings of the 2010 IEEE Sensors, Kona, 2010.

39 H. Yousef, M. Boukallel и K. Althoefer, «Tactile sensing for dexterous in-hand manipulation in robotics-A review,» Sens. Actuators A Phys, p. 171-187, 2011. 
УДК: 617-7

\title{
МЕТОДЫ ИЗМЕРЕНИЯ НАПРЯЖЕНИЙ НА ГРАНИЦЕ ПРИЕМНАЯ ГИЛЬЗА - ОСТАТОЧНАЯ КОНЕЧНОСТЬ
}

\author{
Мельник A. В., асист. кафедры \\ annamelnyk1996@gmail.com \\ Худецкий И. Ю., д.мед.н., проф. \\ igorkhudetskyy@gmail.com \\ Антонова-Рафи Ю. В., к.т.н., доц. \\ antonova-rafi@ukr.net \\ Национальный технический университет Украины \\ «Киевский политехнический институт имени Игоря Сикорского», \\ г. Киев, Украина
}

Реферат - частота ампутаций нижних конечностей растет во всем мире из-за высокого уровня дорожно-транспортных происшествий и заболеваний. Транстибиальные ампутанты часто используют протез как реабилитаиионное средство для восстановления повседневной деятельности. Протез состоит из нескольких важных компонентов, таких как приемная гильза, удлинитель, лодыжка и стопа. Приемная гильза обеспечивает соединение между остаточной конечностью (культей) и другими компонентами протезного устройства. Установка и конструкция приемной гильзы является сложной процедурой из-за уникальности и сложности остаточной конечности каждого ампутанта. Неудобный протез из-за неправильной установки на остаточной зоне разъема конечности может привести к чрезмерным нагрузкам, пистонтов (вертикальные движения внутри гнезда), раздражению кожи, язвам и даже к потенщиальной реампутации. Распределение напряжений между остаточной конечностью и приемной гильзой при транстибиальний ампутации рассматривается как прямой показатель качества приспособления и комфорта приемной гильзы. В связи с этим, исследователи очень заинтересованы в количественной оценке этих напряжений на границе раздела, чтобы оценить степень любого потенциального повреждения, вызванного приемной гильзой на остаточные ткани конечностей. В течение последних 50 лет были использованы различные методы измерения для определения локализации чрезмерных напряжений, которые могут привести к повреждению кожных покровов, сравнения распределения напряжений в различных конструкциях приемных гильз, а также для оценки системь амортизации при протезировании нижних конечностей. Результаты таких методов измерения способствовали совершенствованию конструкиии и монтажа транстибиальних приемных гильз. Эта статья имеет иелью осмотреть принципы работы, преимущества и недостатки традиционных и новых методов, используемых для измерения напряжения на границе приемная гильза - остаточная концовка. В статье также осмотрено эволюиию различных конщепций приемных гильз и исследований напряжений на границе приемная гильза - остаточная кониовка, проведенных за последние пять десятилетий, предоставлено представление о последних тенденщиях в дизайне приемных гильз и приведены соображения относительно эффективных инструментов измерения напряжений, которые приводят к созданию функциональной приемной гильзы..

Ключевые слова: приемная гильза; транстибиальний ампутант; измерения напряжений; остаточная конечность, тензодатчики, пьезорезистивные датчики, пьезоэлектрические датчики, емкостные датчики, оптические датчики. 


\title{
METHODS OF MEASURING STRESSES AT THE BOUNDARY OF THE RECEIVING SLEEVE - THE RESIDUAL LIMB
}

\author{
Melnik $\boldsymbol{H}$. $\boldsymbol{V}$., assistant of the department \\ annamelnyk1996@gmail.com \\ Khudetsky I. Y., Doctor of Medical Sciences, prof. \\ igorkhudetskyy@gmail.com \\ Antonova-Rafi J. V., Ph.D., Associate Professor, \\ antonova-rafi@ukr.net \\ National Technical University of Ukraine \\ "Kyiv Polytechnic Institute named after Igor Sikorsky", \\ Kyiv, Ukraine
}

\begin{abstract}
- the frequency of amputations of the lower extremities is increasing worldwide due to the high level of traffic accidents and vascular diseases. Transstibular amputees often use a prosthesis as a rehabilitation tool to restore daily activities. The prosthesis consists of several important components, such as a receiving sleeve, extension cord, ankle and foot. The receiving sleeve provides a connection between the residual limb (stump) and other components of the prosthetic device. Installation and construction of the receiving sleeve is the most difficult procedure due to the uniqueness and complexity of the residual limb of each amputee. Inconvenient prostheses due to improper installation of the limb connector on the residual area can lead to excessive loads, pistons (vertical movements inside the socket), skin irritation and ulcers, and even potential reamputation. The stress distribution between the residual limb and the receiving sleeve in transtibial amputation is considered as a direct indicator of the quality of the device and the comfort of the receiving sleeve. Therefore, researchers are very interested in quantifying these stresses at the interface to assess the extent of any potential damage caused by the receiving sleeve to residual limb tissue. Over the last 50 years, various measurement methods have been used to determine the locations of excessive stresses that can damage the skin, to compare the stress distribution in different designs of receiving sleeves, and to evaluate the damping system in prosthetics of the lower extremities. The results of such measurement methods contributed to the improvement of the design and installation of transtibial receiving sleeves. This article aims to review the principles of operation, advantages and disadvantages of traditional and new methods used to measure the voltage at the boundary of the receiving sleeve - the residual limb. The article also examines the evolution of different concepts of receiving sleeves and studies of stresses at the receiving sleeve - residual limb, conducted over the past five decades, provides an overview of recent trends in receiving sleeve design and discusses effective tools for measuring stresses that lead to functional receiving sleeve.
\end{abstract}

Key words: receiving sleeve; transtibial amputant; stress measurement; residual limb, strain gauges, piezoresistive sensors, piezoelectric sensors, capacitive sensors, optical sensors. 